\title{
Brain Mitochondria, Aging, and Parkinson's Disease
}

\author{
Mario Rango ${ }^{1,2, *(1)}$ and Nereo Bresolin ${ }^{1,2}$ \\ 1 Parkinson's Disease Center, Neurology Unit, Department of Neuroscience and Mental Health, \\ Fondazione IRCCS Ca' Granda Ospedale Maggiore Policlinico, 20100 Milan, Italy; nereo.bresolin@unimi.it \\ 2 Università degli Studi of Milan, 20100 Milan, Italy \\ * Correspondence: mariocristia@yahoo.it
}

Received: 15 February 2018; Accepted: 7 May 2018; Published: 11 May 2018

\begin{abstract}
This paper reconsiders the role of mitochondria in aging and in Parkinson's Disease (PD). The most important risk factor for PD is aging. Alterations in mitochondrial activity are typical of aging. Mitochondrial aging is characterized by decreased oxidative phosphorylation, proteasome activity decrease, altered autophagy, and mitochondrial dysfunction. Beyond declined oxidative phosphorylation, mitochondrial dysfunction consists of a decline of beta-oxidation as well as of the Krebs cycle. Not inherited mitochondrial DNA (mtDNA) mutations are acquired over time and parallel the decrease in oxidative phosphorylation. Many of these mitochondrial alterations are also found in the PD brain specifically in the substantia nigra (SN). mtDNA deletions and development of respiratory chain deficiency in SN neurons of aged individuals as well as of individuals with PD converge towards a shared pathway, which leads to neuronal dysfunction and death. Finally, several nuclear genes that are mutated in hereditary PD are usually implicated in mitochondrial functioning to a various extent and their mutation may cause mitochondrial impairment. In conclusion, a tight link exists between mitochondria, aging, and PD.
\end{abstract}

Keywords: mitochondria; aging; Parkinson's disease; genes; oxidative phosphorylation

\section{Introduction}

High energy requirements tissues such as the brain are highly dependent on mitochondria. Mitochondria are intracellular organelles deriving and storing energy through the respiratory chain by oxidative phosphorylation $[1,2]$. In a single neuron, hundreds to thousands of mitochondria are contained. Mitochondria have several copies of the mitochondrial genome that consists of a $16.5 \mathrm{~kb}$ circular DNA molecule [2,3] that, in turn, provides the template for 13 essential proteins of the respiratory chain. In a mitochondrion, there are more than 900 proteins and most of them are encoded by the nuclear genome [2,3]. Several diseases are caused by inherited mutations in mitochondrial DNA (mtDNA) [4]. If mutations occur in one single cell, all copies of the mitochondrial genome are called homoplasmic while these copies are otherwise called heteroplasmic. Not inherited mtDNA mutations are called somatic mutations and appear over time. Heteroplasmic mtDNA mutations derive clonally from expansion of single mitochondria with a resulting normal and respiratory-deficient mitochondria mixture within the same cell. Mutated mtDNA replication is better when compared to wild-type mtDNA, which facilitates its clonal expansion. Once mutated mtDNA reaches at least $60 \%$, the cell will have deficient respiration and will accumulate additional mtDNA mutations until cell death $[3,4]$.

Somatic mtDNA mutations are important in aging and disease such as Parkinson's disease (PD) [5]. PD is a neurodegenerative common movement disorder with bradykinesia, rigidity, and resting tremor [5]. PD results mostly from the loss of dopaminergic neurons in the substantia nigra (SN) pars compacta (pc) region [5]. SN dopaminergic neurons are lost in an age and mitochondrial dysfunction related way [6,7]. 
When compared to other neurons, SN dopaminergic neurons have more mtDNA deletions, which is shown by two independent studies [6,7]. In these two studies, both in SN neurons of aged subjects and of subjects with PD, the load of mtDNA mutations paralleled the deficiency of the respiratory chain, which suggests that a common cell mechanism is at play in the two conditions.

\section{Mitochondrial Activity in Aging}

Aging, at the cell level, is an increasingly incapacity to recycle organelles and macromolecules [8,9].

In aging, proteasome activity decreases, autophagy is impaired, and mitochondrial dysfunction emerges with an activity decrease of oxidative phosphorylation, beta-oxidation, and Krebs cycle [10] as well as an increase of oxidative stress that, in turn, damages mitochondria [10].

Mitochondria DNA is very vulnerable [10]. The aging process is tightly linked to mtDNA deletions and point mutations and to reactive oxygen species (ROS). Additionally, mtDNA deletions and point mutations accumulate over time. This leads to energetics impairment, increased ROS production, mtDNA lesions, and the decline of mitochondrial respiration.

ROS target mtDNA since there are no histones and efficacious proofreading systems, this brings more point mutations and deletions [10]. In the mitochondria, deletions expand clonally over time and their number correlates linearly with the cell age.

Mitochondria produce ROS through their several electron carriers but, at the same time, have anti-oxidative capacities. The overexpression of mitochondrial antioxidant enzymes prolongs life [10] both in Drosophila and in mice.

It has been shown that, in old subjects, human frontal cortex oxidative stress damages genes involved in mitochondrial function [10].

In a primate model of aging [11], basal ganglia senescence was under lied by altered mitochondrial function and motor decline. In this model, older animals had minor motor activity than younger animals. In aged monkeys, ATP synthesis was reduced in SN and putamen (PUT). Additionally, pyruvate dehydrogenase activity and calcium buffering capacity were decreased in PUT. A decline in mitochondrial and motor function in the basal ganglia were correlated [11].

\section{Aging, Mitochondria, and Parkinson Disease}

Aging is the most important risk factor for PD [8,12,13]. In PD as in aging [14], there are similar changes in mitochondria such as reduced activity of complex I and IV, increased mtDNA deletions, swollen neuronal mitochondria, and reduced activity of PGC-1_in the SNpc [15]. PGC-1_ is a transcriptional co-activator that regulates the expression of nuclear genes involved in mitochondrial genesis and oxidative phosphorylation and controls genes involved in the cell wear to oxidative stress.

\subsection{Mitochondrial Dysfunction within Substantia Nigra Neurons}

In about half of individuals, those who are older than 85 have mild parkinsonian signs [16]. Old subjects have neuronal loss. Specifically, within the SN, the dopaminergic neurons of the pars compacta are lost and this brain region also shows more pathological changes with normal aging than any other region. The pathological distinctive feature of PD is the loss of dopaminergic neurons in the SNpc [16]. 1-Methyl-4-phenylpyridinium (MPP+) causes parkinsonism and SN cell loss by inhibiting complex I $[17,18]$. Complex I activity and protein expression are decreased in brains of PD subjects $[19,20]$. SN neurons are very sensible for mitochondrial dysfunction, which causes loss of SN neurons.

All in all, reviewed data suggests that PD may be a local expression of aging on cell populations which, by their characteristics (high number of mitochondria as well as synaptic terminals and unmyelinated axons) are highly vulnerable to the agents promoting aging. 


\subsection{Respiratory Deficiency}

The inhibition of complex I cause parkinsonism and its inhibitors, MPP+ and rotenone, cause death of SN neurons $[17,21]$. Respiratory deficiency is characterized by a decline in the complex IV, which is shown by cytochrome c oxidase/succinate dehydrogenase (COX/SDH) coloring [22]. In PD patients, around $3 \%$ of SN neurons are cytochrome c oxidase (COX) deficient with a few studies reporting up to $30 \%$ COX deficiency in some cases [6,7] when compared to $1 \%$ in age-matched subjects. Respiratory impairment brings impaired ATP synthesis. Compromised production of ATP has been shown in PD brain tissues with minor pathological involvement and with high mitochondrial activity such as the visual cortex [23].

\section{3. mtDNA Mutation Load}

In PD SN, when mtDNA deletions reach 50\%, a respiratory (COX) deficiency is detected [6,22]. The mtDNA deletion percentage reaches its maximum in SN followed by [24-28] the basal ganglia, cerebellum, and cortical areas. mtDNA deletions appear during mtDNA damage repair [29] as a consequence of the oxidative environment. In mice with deficient mtDNA polymerase (POLG gene), alterations of mtDNA integrity brings decreased dopaminergic neurons and an aging phenotype [30,31] together with osteoporosis, kyphosis, weight loss, and increased somatic mtDNA mutations [31]. Additionally, the knock-out of the mitochondrial transcription factor A (TFAM) within dopaminergic neurons causes progressive parkinsonism, the accumulation of protein inclusions, and dopaminergic neuron loss together with decreased mtDNA expression [30]. In old Twinkle mutant mice [32], it has been shown that motor defects are present together with reduced SN neurons and accumulation of mtDNA.

\subsection{Genes and Key Mitochondrial Processes}

Alterations in genes implied in early onset PD can cause mitochondrial changes. For example, in Drosophila and cell cultures, the knockout of PINK1, Parkin, Alpha-synuclein (Alpha-syn), and DJ-1 alters mitochondrial morphology [33-37] in several ways. Alpha-syn mutations change mitochondrial distribution and ultrastructure [36]. PINK1 and Parkin mutations cause modification of the mitochondrial electron density and fragmentation of the mitochondrial network [33,34]. $D J-1$ loss is accompanied by mitochondrial fragmentation plus decreased mitochondrial membrane potential [38,39].

Leucine-rich repeat kinase (LRRK2) mutation also causes mitochondrial changes [40].

Calcium is important to keep pace making activity of the SN neurons and its handling depends on several genes linked to mitochondria.

Mitofusin 2 ( $m f n 2$ ) deals with handling of mitochondrial calcium and mitochondrial fusion and is crucial for the integrity of SN-to-striatum projections [41]. DJ-1 modulates mitochondrial calcium handling as well as morphology [42]. Overexpression of Parkin potentiates the mitochondrial calcium handling [43].

Mitochondrial degradation through mitophagy is associated with mitochondrial membrane potential $(\Delta \Psi \mathrm{m})$ loss [44]. Mitophagy depends on the dissipation of $\Delta \Psi \mathrm{m}$ [44] and $\Delta \Psi \mathrm{m}$ orientates directionality of neuronal mitochondria. Most of the mitochondria with a low membrane potential are transported towards the cell body [45]. PINK1 and Parkin are implicated in mitophagy through the targeting and degradation of mitochondria. In addition, the interaction of PINK1 and Parkin seems to facilitate the turnover of respiratory chain components [46].

\subsection{Mitochondria and Alpha-Synuclein}

Lewy body characterizes PD [5] and contains Alpha-syn. Misfolding and accumulation of the Alpha-syn protein are hypothesized to be two main mechanisms in the pathogenesis of PD. 
There is still little understanding of the interaction between Alpha-syn and mitochondria. Alpha-syn enters the mitochondria in an energy-dependent way [47]. Cardiolipin facilitates the interaction of Alpha-syn with the mitochondrial membranes. Alpha-syn has antioxidant property through cyclic oxidation/reduction of methionine residues in the N-terminal. Oxidation is located in the membrane with peroxidized lipids close to the protein while methionine is reduced in the cytosol.

The strongest toxic effect of Alpha-syn is right in the mitochondria. Its accumulation within mitochondria causes complex I malfunctioning, increased ROS synthesis, and reduced $\Delta \Psi \mathrm{m}$ [48-50] that, in turn, are likely to exacerbate the mitochondrial impairment present in old SN neurons.

Alpha-syn also impairs the mitochondria delivery and transport and is characterized by modification of the mitochondrial cristae in cell culture. In addition, rotenone-dependent toxicity is increased by overexpression of mutated Alpha-syn while, conversely, Alpha-syn knockout gives resistance to 1-methyl-4-phenyl-1,2,3,6-tetrahydropyridine (MPTP) intoxication in mice.

Lastly, accumulated Alfa-syn interacts with motor proteins, which reduces axonal transport and alters the distribution of mitochondria along the neuron [51].

\section{Mitochondria and the Ubiquitin Proteasome System in Aging and Parkinson Disease}

Malfunctioning of the mitochondria and of the ubiquitin proteasome system (UPS) characterizes the aging process as well as several age-related diseases such as PD [52].

The UPS keeps mitochondrial homeostasis by controlling the proteome and mitophagy. Mitochondrial dysfunction alters homeostasis of cellular proteins through oxidative damage. In models, proteasome activation improves the aging process by increasing lifespan. In PD, it is difficult to isolate UPS impairment from mitochondrial dysfunction.

\section{Mitochondrial Diseases and Parkinson Disease Symptoms}

SN changes are more tightly associated with acquired rather than inherited mitochondrial defects [50]. In patients with mitochondrial disorders, extrapyramidal features are rare. However, there are reports on the association between Parkinsonism and POLG mutations [53-56]. POLG is the most common inherited mutation in patients with parkinsonism and mitochondrial diseases. However, sometimes parkinsonism is associated with point mutations of other genes [57,58].

The haplogroups K, J, and possibly T and superhaplogroup JT protect against PD. However, this is only within European populations [59-61]. The superhaplogroup HV has been associated with a risk of developing PD with advancing age [59].

\section{Latest Findings}

New evidence on mitochondria, age, and PD has emerged in the last five years.

Popa-Wagner et al. [62] have shown that the turnover rates for DMN11 and FIS1, which are proteins implicated in mitochondrial biogenesis, mitophagy, and fission go in opposite directions in the cerebellum of 22-month-old C57BL6j mice when compared to three-month-old mice. Unlike previous studies that have reported decreased turnover rates for the mitochondrial respiratory complexes of aged rodents, the authors found increased turnover rates for mitochondrial proteins of the oxidative phosphorylation chain in the aged mice when compared to young mice.

Cooper et al. [63] investigating the relationship between mitochondrial function, dopamine neuronal dysfunction, and death for $p d r-1 / P R K N$, pink-1/PINK1, and $d j r-1.1 / D J-1$ found that $p d r-1$ and pink-1 mutants had deficitary dopamine-dependent behaviors while djr-1.1 mutants showed an increased sensitivity to oxidative stress. Additionally, they found that djr-1.1 mutants exhibit increased mitochondrial fragmentation together with a decreased rate of oxidative phosphorylation and ATP levels and that $p d r-1$ and pink-1 mutants showed an accumulation of dysfunctional mitochondria with age, which leads to activation of the mitochondrial unfolded protein response (mitoUPR). By preventing the upregulation of the mitoUPR, they obtained decreased lifespan and dopamine neuronal loss. 
Hauser et al. found [64] that DJ-1 knockout in both rat and mouse brains results in an age-dependent accumulation of hexokinase 1 in the cytosol (away from its usual location at the mitochondria) with subsequent activation of the polyol pathway of glucose metabolism in vivo. In their work, dissociation of hexokinases from mitochondria inhibited the PINK1/parkin pathway, which suggests that hexokinases are an important link between three major genetic causes of early onset PD.

Geldenhuys et al. [65] showed that loss of mitoNEET (CISD1), which is an iron-sulfur containing protein, regulates mitochondrial bioenergetics and results in mitochondrial dysfunction and loss of striatal dopamine and tyrosine hydroxylase. Mitochondria from mice lacking mitoNEET were dysfunctional with elevated ROS and reduced ATP synthesis. In knockout mice, gait analysis revealed a shortened stride length and decreased rotarod performance consistent with the loss of striatal dopamine. This suggests that mitoNEET KO mice exhibit many of the characteristics of early neurodegeneration in PD.

Song et al. [66] have shown that selective overexpression of the stress protein in heme oxygenase-1 (HO-1) in astrocytes of GFAP.HMOX1 transgenic mice between 8.5 and 19 months of age results in nigrostriatal hypodopaminergia and mitochondrial damage/mitophagy associated with locomotor incoordination and stereotypy. These GFAP.HMOX $1^{8.5-19 \mathrm{~m}}$ mice are affected by parkinsonism unlike younger GFAP.HMOX ${ }^{0-12 \mathrm{~m}}$ mice who have schizophrenia-like features. This depends on whether the glial HO-1 response is engaged prior to or following the maturation of dopaminergic circuitry.

Genetic deletion of Sirtuin-3 (Sirt3), which is a mitochondrial deacetylase, increases oxidative stress and decreases the membrane potential of mitochondria in SNpc dopaminergic neurons. Studies from Shi et al. [67] have suggested that an age-related decline in Sirt3 protective function is a major factor underlying increasing mitochondrial oxidative stress and loss of SNpc dopaminergic neurons in PD.

Stevens et al. [68]: 11696-701 have shown that, in a mouse model, adult knockout of parkin leads to an age-dependent loss of dopamine neurons and decreases in brain mitochondrial size, number, and protein markers in line with a defect in mitochondrial biogenesis.

In a mouse study, Jiang et al. [69] have shown that mitochondrial functions, mitochondrial fusion/fission-related proteins, and autophagic proteins are more severely affected by MPTP treatment in the elderly than in the young.

In humans, Cabre et al. [70] have shown that protein oxidative and glycoxidative damage significantly increases during human brain aging with a breakpoint at 60 years old together with a decrease in the content of the mitochondrial respiratory chain complex I-IV.

\section{Conclusions}

There is a link between mitochondria, aging, and PD. Several mitochondrial changes are shared and overlap in aging and PD. However, more research still has to be completed to fully elucidate the exact mechanisms underlying and linking the two conditions.

Conflicts of Interest: The authors declare no conflict of interest.

\section{References}

1. Siesjo, B.K. Brain Energy Metabolism; John Wiley \& Sons: New York, NY, USA, 1978.

2. Siegel, G.J.; Albers, R.W.; Agranoff, B.W.; Katzman, R. Basic Neurochemistry; Little Brown: Boston, MA, USA, 1981.

3. Lauri, A.; Pompilio, G.; Capogrossi, M.C. The mitochondrial genome in aging and senescence. Ageing Res. Rev. 2014, 18, 1-15. [CrossRef] [PubMed]

4. Chinnery, P.F. Mitochondrial disease in adults: What's old and what's new? EMBO Mol. Med. 2015, 7, 1503-1512. [CrossRef] [PubMed] 
5. Bradley, W.; Daroff, R.; Fenichel, G.; Jankovic, J. Neurology in Clinical Practice, 4th ed.; Butterworth-Heinemann: London, UK, 2004; pp. 2131-2139.

6. Kraytsberg, Y.; Kudryaviseva, E.; McKee, A.C.; Geula, C.; Kowall, N.W.; Khrapko, K. Mitochondrial DNA deletions are abundant and cause functional impairment in aged human substantia nigra neurons. Nat. Genet. 2006, 38, 518-520. [CrossRef] [PubMed]

7. Bender, A.; Krishnan, K.J.; Morris, C.M.; Taylor, G.A.; Reeve, A.K.; Perry, R.H.; Jaros, E.; Hersheson, J.S.; Betts, J.; Klopstock, T.; et al. High levels of mitochondrial DNA deletions in substantia nigra neurons in aging and Parkinson disease. Nat. Genet. 2006, 38, 515-517. [CrossRef] [PubMed]

8. Collier, T.J.; Kanaan, N.M.; Kordower, J.H. Aging and Parkinson's disease: Different sides of the same coin? Mov. Disord. 2017, 32, 983-990. [CrossRef] [PubMed]

9. Wyss-Coray, T. Ageing, neurodegeneration and brain rejuvenation. Nature 2016, 539, 180-186. [CrossRef] [PubMed]

10. Theurey, P.; Pizzo, P. The aging mitochondria. Genes 2018, 9, 22. [CrossRef] [PubMed]

11. Pandya, J.D.; Grondin, R.; Yonutas, H.M.; Haghnazar, H.; Gash, D.M.; Zhang, Z.; Sullivan, P.G. Decreased mitochondrial bioenergetics and calcium buffering capacity in the basal ganglia correlates with motor deficits in a nonhuman primate model of aging. Neurobiol. Aging 2015, 36, 1903-1913. [CrossRef] [PubMed]

12. Collier, T.J.; Kanaan, N.M.; Kordower, J.H. Ageing as a primary risk factor for Parkinson's disease: Evidence from studies of non-human primates. Nat. Rev. Neurosci. 2011, 12, 359-366. [CrossRef] [PubMed]

13. Liu, J.-P. Molecular mechanisms of ageing and related diseases. Clin. Exp. Pharmacol. Physiol. 2014, 41, 445-458. [CrossRef] [PubMed]

14. Hauser, D.N.; Hastings, T.G. Mitochondrial dysfunction and oxidative stress in Parkinson's disease and monogenic Parkinsonism. Neurobiol. Dis. 2013, 51, 35-42. [CrossRef] [PubMed]

15. Phillipson, O.T. Management of the aging risk factor for Parkinson's disease. Neurobiol. Aging 2014, 35, 847-857. [CrossRef] [PubMed]

16. Biskup, S.; Moore, D.J. Detrimental deletions: Mitochondria, aging and Parkinson's disease. Bioessays 2006, 28, 963-967. [CrossRef] [PubMed]

17. Langston, J.W.; Ballard, P.; Tetrud, J.W.; Irwin, I. Chronic Parkinsonism in humans due to a product of meperidine-analog synthesis. Science 1983, 219, 979-980. [CrossRef] [PubMed]

18. Langston, J.W.; Ballard, P.A., Jr. Parkinson's disease in a chemist working with 1-methyl-4-phenyl-1,2,5,6tetrahydropyridine. N. Engl. J. Med. 1983, 309, 310. [PubMed]

19. Schapira, A.H.; Cooper, J.M.; Dexter, D.; Jenner, P.; Clark, J.B.; Marsden, C.D. Mitochondrial complex I deficiency in Parkinson's disease. Lancet 1989, 333, 1269. [CrossRef]

20. Schapira, A.H.; Cooper, J.M.; Dexter, D.; Clark, J.B.; Jenner, P.; Marsden, C.D. Mitochondrial complex I deficiency in Parkinson's disease. J. Neurochem. 1990, 54, 823-827. [CrossRef] [PubMed]

21. Betarbet, R.; Sherer, T.B.; MacKenzie, G.; Garcia-Osuna, M.; Panov, A.V.; Greenamyre, J.T. Chronic systemic pesticide exposure reproduces features of Parkinson's disease. Nat. Neurosci. 2000, 3, 1301-1306. [CrossRef] [PubMed]

22. Douiev, L.; Abu-Libdeh, B.; Saada, A. Cytochrome c oxidase deficiency, oxidative stress, possible antioxidant therapy and link to nuclear DNA damage. Eur. J. Hum. Genet. 2018, 26, 579-581. [CrossRef] [PubMed]

23. Rango, M.; Bonifati, C.; Bresolin, N. Parkinson's disease and brain mitochondrial dysfunction: A functional phosphorous magnetic resonance spectroscopy study. J. Cereb. Blood Flow Metab. 2006, 26, 283-290. [CrossRef] [PubMed]

24. Reeve, A.K.; Krishnan, K.J.; Taylor, G.; Elson, J.L.; Bender, A.; Taylor, R.W.; Morris, C.M.; Turnbull, D.M. The low abundance of clonally expanded mitochondrial DNA point mutations in aged substantia nigra neurons. Aging Cell 2009, 8, 496-498. [CrossRef] [PubMed]

25. Bender, A.; Schwarzkopf, R.M.; McMillan, A.; Krishnan, K.J.; Rieder, G.; Neumann, M.; Elstner, M.; Turnbull, D.M.; Klopstock, T. Dopaminergic midbrain neurons are the prime target for mitochondrial DNA deletions. J. Neurol. 2008, 255, 1231-1235. [CrossRef] [PubMed]

26. Estner, M.; Morris, C.M.; Heim, K.; Bender, A.; Mehta, D.; Jaros, E.; Klopstock, T.; Meitinger, T.; Turnbull, D.M.; Prokisch, H. Expression analysis of dopaminergic neurons in Parkinson's disease and aging links transcriptional dysregulation of energy metabolism to cell death. Acta Neuropathol. 2011, 122, 75-86. [CrossRef] [PubMed] 
27. Corral-Debrinski, M.; Horton, T.; Lott, M.T.; Shoffner, J.M.; Beal, M.F.; Wallace, D.C. Mitochondrial DNA deletions in human brain: Regional variability and increase with advanced age. Nat. Genet. 1992, 2, 324-329. [CrossRef] [PubMed]

28. Soong, N.W.; Hinton, D.R.; Cortopassi, G.; Arnheim, N. Mosaicism for a specific somatic mitochondrial DNA mutation in adult human brain. Nat. Genet. 1992, 2, 318-323. [CrossRef] [PubMed]

29. Krishnan, K.J.; Reeve, A.K.; Samuels, D.C.; Chinnery, P.F.; Blackwood, J.K.; Taylor, R.W.; Wanrooij, S.; Spelbrink, J.N.; Lightowlers, R.N.; Turnbull, D.M. What causes mitochondrial DNA deletions in human cells? Nat. Genet. 2008, 40, 275-279. [CrossRef] [PubMed]

30. Ekstrand, M.I.; Terzioglu, M.; Galter, D.; Zhu, S.; Hofstetter, C.; Lindqvist, E.; Thams, S.; Bergstrand, A.; Hansson, F.S.; Trifunovic, A.; et al. Progressive parkinsonism in mice with respiratory-chain-deficient dopamine neurons. Proc. Natl. Acad. Sci. USA 2007, 104, 1325-1330. [CrossRef] [PubMed]

31. Trifunovic, A.; Wredenberg, A.; Falkenberg, M.; Spelbrink, J.N.; Rovio, A.T.; Bruder, C.E.; Mohammad, B.-Y.; Gidlöf, S.; Oldfors, A.; Wibom, R.; et al. Premature ageing in mice expressing defective mitochondrial DNA polymerase. Nature 2004, 429, 417-423. [CrossRef] [PubMed]

32. Song, L.; Shan, Y.; Lloyd, K.C.; Cortopassi, G.A. Mutant Twinkle increases dopaminergic neurodegeneration, mtDNA deletions and modulates Parkin expression. Hum. Mol. Genet. 2012, 21, 5147-5158. [CrossRef] [PubMed]

33. Clark, I.E.; Dodson, M.W.; Jiang, C.; Cao, J.H.; Huh, J.R.; Seol, J.H.; Yoo, S.J.; Hay, B.A.; Guo, M. Drosophila pink1 is required for mitochondrial function and interacts genetically with parkin. Nature 2006, 441, 1162-1166. [CrossRef] [PubMed]

34. Greene, J.C.; Whitworth, A.J.; Kuo, I.; Andrews, L.A.; Feany, M.B.; Pallanck, L.J. Mitochondrial pathology and apoptotic muscle degeneration in Drosophila parkin mutants. Proc. Natl. Acad. Sci. USA 2003, 100, 4078-4083. [CrossRef] [PubMed]

35. Martin, L.J.; Pan, Y.; Price, A.C.; Sterling, W.; Copeland, N.G.; Jenkins, N.A.; Price, D.L.; Lee, M.K. Parkinson's disease $\alpha$-synuclein transgenic mice develop neuronal mitochondrial degeneration and cell death. J. Neurosci. 2006, 26, 41-50. [CrossRef] [PubMed]

36. Nakamura, K.; Nemani, V.M.; Azarbal, F.; Skibinski, G.; Levy, J.M.; Egami, K.; Munishkina, L.; Zhang, J.; Gardner, B.; Wakabayashi, J.; et al. Direct membrane association drives mitochondrial fission by the Parkinson disease-associated protein alpha-synuclein. J. Biol. Chem. 2011, 286, 20710-20726. [CrossRef] [PubMed]

37. Park, J.; Kim, S.Y.; Cha, G.H.; Lee, S.B.; Kim, S.; Chung, J. Drosophila DJ-1 mutants show oxidative stress-sensitive locomotive dysfunction. Gene 2005, 361, 133-139. [CrossRef] [PubMed]

38. Thomas, K.J.; McCoy, M.K.; Blackinton, J.; Beilina, A.; van der Brug, M.; Sandebring, A.; Miller, D.; Maric, D.; Cedazo-Minguez, A.; Cookson, M.R. DJ-1 acts in parallel to the PINK1/parkin pathway to control mitochondrial function and autophagy. Hum. Mol. Genet. 2011, 20, 40-50. [CrossRef] [PubMed]

39. Wang, X.; Petrie, T.G.; Liu, Y.; Liu, J.; Fujioka, H.; Zhu, X. Parkinson's disease-associated DJ-1 mutations impair mitochondrial dynamics and cause mitochondrial dysfunction. J. Neurochem. 2012, 121, 830-839. [CrossRef] [PubMed]

40. Mortiboys, H.; Johansen, K.K.; Aasly, J.O.; Bandmann, O. Mitochondrial impairment in patients with Parkinson disease with the G2019S mutation in LRRK2. Neurology 2010, 75, 2017-2020. [CrossRef] [PubMed]

41. Lee, S.; Sterky, F.H.; Mourier, A.; Terzioglu, M.; Cullheim, S.; Olson, L.; Larsson, N.G. Mitofusin 2 is necessary for striatal axonal projections of midbrain dopamine neurons. Hum. Mol. Genet. 2012, 21, 4827-4835. [CrossRef] [PubMed]

42. Ottolini, D.; Calì, T.; Negro, A.; Brini, M. The Parkinson disease-related protein DJ-1 counteracts mitochondrial impairment induced by the tumour suppressor protein p53 by enhancing endoplasmic reticulum-mitochondria tethering. Hum. Mol. Genet. 2013, 22, 2152-2168. [CrossRef] [PubMed]

43. Calì, T.; Ottolini, D.; Negro, A.; Brini, M. $\alpha$-Synuclein controls mitochondrial calcium homeostasis by enhancing endoplasmic reticulum-mitochondria interactions. J. Biol. Chem. 2012, 287, 17914-17929. [CrossRef] [PubMed]

44. Twig, G.; Elorza, A.; Molina, A.J.; Mohamed, H.; Wikstrom, J.D.; Walzer, G.; Stiles, L.; Haigh, S.E.; Katz, S.; Las, G.; et al. Fission and selective fusion govern mitochondrial segregation and elimination by autophagy. EMBO J. 2008, 27, 433-446. [CrossRef] [PubMed] 
45. Miller, K.E.; Sheetz, M.P. Axonal mitochondrial transport and potential are correlated. J. Cell Sci. 2004, 117 Pt 13, 2791-2804. [CrossRef] [PubMed]

46. Vincow, E.S.; Merrihew, G.; Thomas, R.E.; Shulman, N.J.; Beyer, R.P.; MacCoss, M.J.; Pallanck, L.J. The PINK1-Parkin pathway promotes both mitophagy and selective respiratory chain turnover in vivo. Proc. Natl. Acad. Sci. USA 2013, 110, 6400-6405. [CrossRef] [PubMed]

47. Devi, L.; Raghavendran, V.; Prabhu, B.M.; Avadhani, N.G.; Anandatheerthavarada, H.K. Mitochondrial import and accumulation of $\alpha$-synuclein impair complex I in human dopaminergic neuronal cultures and Parkinson disease brain. J. Biol. Chem. 2008, 283, 9089-9100. [CrossRef] [PubMed]

48. Parihar, M.S.; Parihar, A.; Fujita, M.; Hashimoto, M.; Ghafourifar, P. Mitochondrial association of alpha-synuclein causes oxidative stress. Cell. Mol. Life Sci. 2008, 65, 1272-1284. [CrossRef] [PubMed]

49. Botella, J.A.; Bayersdorfer, F.; Schneuwly, S. Superoxide dismutase overexpression protects dopaminergic neurons in a Drosophila model of Parkinson's disease. Neurobiol. Dis. 2008, 30, 65-73. [CrossRef] [PubMed]

50. Bobela, W.; Aebischer, P.; Schneider, B.L. Alpha-synuclein as a mediator in the interplay between aging and Parkinson's disease. Biomolecules 2015, 5, 2675-2700. [CrossRef] [PubMed]

51. Bose, A.; Beal, M.F. Mitochondrial dysfunction in Parkinson's disease. J. Neurochem. 2016, 139, $216-231$. [CrossRef] [PubMed]

52. Ross, J.M.; Olson, L.; Coppotelli, G. Mitochondrial and ubiquitin proteasome system dysfunction in ageing and disease: two sides of the same coin? Int. J. Mol. Sci. 2015, 16, 19458-19476. [CrossRef] [PubMed]

53. Reeve, A.; Meagher, M.; Lax, N.; Simcox, E.; Hepplewhite, P.; Jaros, E.; Turnbull, D. The impact of pathogenic mitochondrial DNA mutations on substantia nigra neurons. J. Neurosci. 2013, 33, 10790-10801. [CrossRef] [PubMed]

54. Anvret, A.; Westerlund, M.; Sydow, O.; Willows, T.; Lind, C.; Galter, D.; Belin, A.C. Variations of the CAG trinucleotide repeat in DNA polymerase $\gamma$ (POLG1) is associated with Parkinson's disease in Sweden. Neurosci. Lett. 2010, 485, 117-120. [CrossRef] [PubMed]

55. Balafkan, N.; Tzoulis, C.; Müller, B.; Haugarvoll, K.; Tysnes, O.B.; Larsen, J.P.; Bindoff, L.A. Number of CAG repeats in POLG1 and its association with Parkinson disease in the Norwegian population. Mitochondrion 2012, 12, 640-643. [CrossRef] [PubMed]

56. Eerola, J.; Luoma, P.T.; Peuralinna, T.; Scholz, S.; Paisan-Ruiz, C.; Suomalainen, A.; Singleton, A.B.; Tienari, P.J. POLG1 polyglutamine tract variants associated with Parkinson's disease. Neurosci. Lett. 2010, 477, 1-5. [CrossRef] [PubMed]

57. Casali, C.; Bonifati, V.; Santorelli, F.M.; Casari, G.; Fortini, D.; Patrignani, A.; Fabbrini, G.; Carrozzo, R.; D'Amati, G.; Locuratolo, N.; et al. Mitochondrial myopathy, parkinsonism, and multiple mtDNA deletions in a Sephardic Jewish family. Neurology 2001, 56, 802-805. [CrossRef] [PubMed]

58. Horvath, R.; Kley, R.A.; Lochmüller, H.; Vorgerd, M. Parkinson syndrome, neuropathy, and myopathy caused by the mutation A8344G (MERRF) in tRNALys. Neurology 2007, 68, 56-58. [CrossRef] [PubMed]

59. Hudson, G.; Nalls, M.; Evans, J.R.; Breen, D.P.; Winder-Rhodes, S.; Morrison, K.E.; Morris, H.R.; Williams-Gray, C.H.; Barker, R.A.; Singleton, A.B.; et al. Two-stage association study and meta-analysis of mitochondrial DNA variants in Parkinson disease. Neurology 2013, 80, 2042-2048. [CrossRef] [PubMed]

60. Latsoudis, H.; Spanaki, C.; Chlouverakis, G.; Plaitakis, A. Mitochondrial DNA polymorphisms and haplogroups in Parkinson's disease and control individuals with a similar genetic background. J. Hum. Genet. 2008, 53, 349-356. [CrossRef] [PubMed]

61. Mehta, P.; Mellick, G.D.; Rowe, D.B.; Halliday, G.M.; Jones, M.M.; Manwaring, N.; Vandebona, H.; Silburn, P.A.; Wang, J.J.; Mitchell, P.; et al. Mitochondrial DNA haplogroups J and K are not protective for Parkinson's disease in the Australian community. Mov. Disord. 2009, 24, 290-292. [CrossRef] [PubMed]

62. Popa-Wagner, A.; Sandu, R.E.; Cristin, C.; Uzoni, A.; Welle, K.A.; Hryhorenko, J.R.; Ghaemmaghami, S. Increased degradation rates in the components of the mitochondrial oxidative phosphorylation chain in the cerebellum of old mice. Front. Aging Neurosci. 2018, 10, 32. [CrossRef] [PubMed]

63. Cooper, J.F.; Machiela, E.; Dues, D.J.; Spielbauer, K.K.; Senchuk, M.M.; Van Raamsdonk, J.M. Activation of the mitochondrial unfolded protein response promotes longevity and dopamine neuron survival in Parkinson's disease models. Sci. Rep. 2017, 7, 16441. [CrossRef] [PubMed]

64. Hauser, D.N.; Mamais, A.; Conti, M.M.; Primiani, C.T.; Kumaran, R.; Dillman, A.A.; Langston, R.G.; Beilina, A.; Garcia, J.H.; Diaz-Ruiz, A.; et al. Hexokinases link DJ-1 to the PINK1/parkin pathway. Mol. Neurodegener. 2017, 12, 70. [CrossRef] [PubMed] 
65. Geldenhuys, W.J.; Benkovic, S.A.; Lin, L.; Yonutas, H.M.; Crish, S.D.; Sullivan, P.G.; Darvesh, A.S.; Brown, C.M.; Richardson, J.R. MitoNEET (CISD1) knockout mice show signs of striatal mitochondrial dysfunction and a Parkinson's disease phenotype. ACS Chem. Neurosci. 2017, 8, 2759-2765. [CrossRef] [PubMed]

66. Song, W.; Cressatti, M.; Zukor, H.; Liberman, A.; Galindez, C.; Schipper, H.M. Parkinsonian features in aging GFAP.HMOX1 transgenic mice overexpressing human $\mathrm{HO}_{-1}$ in the astroglial compartment. Neurobiol. Aging 2017, 58, 163-179. [CrossRef] [PubMed]

67. Shi, H.; Deng, H.X.; Gius, D.; Schumacker, P.T.; Surmeier, D.J.; Ma, Y.C. Sirt3 protects dopaminergic neurons from mitochondrial oxidative stress. Hum. Mol. Genet. 2017, 26, 1915-1926. [CrossRef] [PubMed]

68. Stevens, D.A.; Lee, Y.; Kang, H.C.; Lee, B.D.; Lee, Y.I.; Bower, A.; Jiang, H.; Kang, S.U.; Andrabi, S.A.; Dawson, V.L.; et al. Parkin loss leads to PARIS-dependent declines in mitochondrial mass and respiration. Proc. Natl. Acad. Sci. USA 2015, 112, 11696-11701. [CrossRef] [PubMed]

69. Jiang, N.; Bo, H.; Song, C.; Guo, J.; Zhao, F.; Feng, H.; Ding, H.; Ji, L.; Zhang, Y. Increased vulnerability with aging to MPTP: The mechanisms underlying mitochondrial dynamics. Neurol. Res. 2014, 36, 722-732. [CrossRef] [PubMed]

70. Cabré, R.; Naudí, A.; Dominguez-Gonzalez, M.; Ayala, V.; Jové, M.; Mota-Martorell, N.; Piñol-Ripoll, G.; Gil-Villar, M.P.; Rué, M.; Portero-Otín, M.; et al. Sixty years old is the breakpoint of human frontal cortex aging. Free Radic. Biol. Med. 2017, 103, 14-22. [CrossRef] [PubMed]

(C) 2018 by the authors. Licensee MDPI, Basel, Switzerland. This article is an open access article distributed under the terms and conditions of the Creative Commons Attribution (CC BY) license (http://creativecommons.org/licenses/by/4.0/). 